\title{
Mengungkap Praktik Akuntansi Manajemen Strategik Terhadap Kinerja Keuangan Pada Badan Usaha Milik Desa (BUMDESA) Bhuana Utama Desa Panji
}

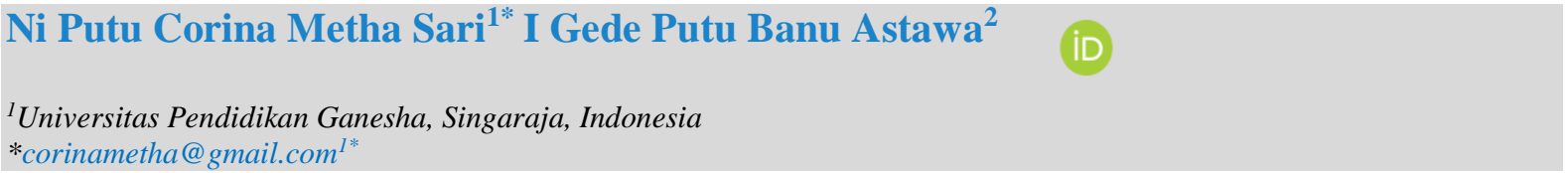

\section{Abstrak}

Penelitian ini bertujuan untuk mengungkap praktik akuntansi manajemen strategik terhadap kinerja keuangan yang ada pada Badan Usaha Milik Desa (Bumdesa) Bhuana Utama Desa Panji. Berdasarkan sisi akuntansi yaitu dari laporan laba rugi pada Bumdesa Panji mengalami peningkatan laba secara signifikan dari tahun ke tahun, maka hal ini tentu memerlukan suatu perencanaan strategis oleh manajemen Bumdesa dengan tujuan untuk mempertahankan dan meningkatkan laba tersebut ke depannya. Penelitian ini merupakan penelitian deskriptif kualitatif dengan metode yang digunakan yaitu observasi, wawancara, dan analisis dokumen. Hasil yang didapatkan pada penelitian ini bahwa akuntansi manajemen strategik dapat digunakan oleh suatu badan usaha dalam melakukan analisis untuk meningkatkan laba pada usahanya.

Kata Kunci : Akuntansi Manajemen Strategik, Kinerja Keuangan, Badan Usaha Milik Desa

\section{Abstract}

This study aims to reveal strategic management accounting practices on financial performance in the Village Owned Enterprises (Bumdesa) Bhuana Utama Panji Village. Based on the profit and loss report on Bumdesa Panji, which gets a significant increase in profit from year to year, a strategic plan can be made by the Bumdesa management with the aim of maintaining and increasing these profits in the future. This research is a qualitative descriptive study with the methods used are observation, interviews, and document analysis. The results obtained in this study that strategic management accounting can be used by a business entity in conducting analysis to increase profits in its business.

Keywords: Strategic Management Accounting, Financial Performance, Village-Owned Enterprises

\section{Pendahuluan}

Desa Panji merupakan salah satu desa yang terletak di Kecamatan Sukasada, Kabupaten Buleleng, Bali. Dalam menjalankan sistem pemerintahannya tentu Desa Panji memiliki stuktur organisasi dan program kerja untuk melancarkan segala kegiatan yang dilakukan di Desa tersebut. Kegiatan-kegiatan yang dilakukan tidak terlepas dari tujuannya dalam mensejahterakan masyarakat yang ada di desa tersebut. Ada banyak cara yang dapat dilakukan untuk mensejahterakan kehidupan masyarakat di Desa Panji, salah satunya adalah dengan membentuk suatu badan yang mampu melihat dan melakukan pengelolaan terhadap potensi yang ada di Desa tersebut dan kemudian disesuaikan dengan kebutuhan masyarakat desanya.

Desa Panji memiliki beberapa badan usaha atau organisasi yang mampu untuk membantu dalam mengembangkan potensi dan usaha yang ada pada desanya. Badan usaha atau organisasi tersebut yaitu Badan Usaha Milik Desa (Bumdesa), PKK, Kelompok Wanita Tani (KWT), dan Lembaga Pengelolaan Hutan Desa (LPHD). Lembaga Pengelolaan Hutan

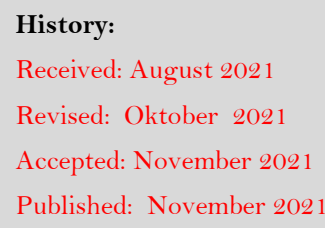

Licensed: This work is licensed under a Creative Commons Attribution 3.0 License (c) (†) (?) 
Desa (LPHD) ini bergerak dalam bidang lingkungan. Menurut Kurniawan et al., (2020), potensi Desa Panji ini dibagi menjadi tiga, yaitu potensi kehutanan, potensi pertanian, dan potensi budaya. Hutan Desa Panji ini terdiri dari ekowisata, produk madu, spot air terjun. Pada sektor kehutanan, hutan Desa Panji dapat dikembangkan sebagai area perkemahan bagi pengunjung yang ingin melakukan kemah di hutan ini sehingga dapat mendatangkan keuntungan bagi Desa Panji.

Menurut UU Nomor 23 tahun 2014 Tentang Pemerintahan Daerah dan PP Nomor 72 tahun 2005 dinyatakan bahwa, Badan Usaha Milik Desa merupakan suatu badan yang dibentuk oleh pemerintah di suatu desa untuk meningkatkan pendapatan masyarakat dan desa tersebut dengan menyesuaikan kebutuhan dan potensi yang ada di desanya. Dalam hal ini pemerintah Desa Panji juga turut andil dalam meningkatkan kesejahteraan masyarakat dan desanya dengan membentuk suatu badan usaha yang diberi nama Badan Usaha Milik Desa (Bumdesa) Bhuana Utama.

Awalnya Badan Usaha Milik Desa yang ada di Desa Panji ini memilki nama Badan Pengelola Air Bersih (BPAB), namun berdasarkan Musyawarah Desa yang dilakukan, kemudian dikeluarkanlah Peraturan Desa Panji Nomor 9 Tahun 2016 Tentang Pendirian Badan Usaha Milik Desa (Bumdesa) Desa Panji maka diubahlah Badan Pengelola Air Bersih (BPAB) ini menjadi Badan Usaha Milik Desa (Bumdesa) yang diberi nama Bumdesa Bhuana Utama Desa Panji. Peraturan lainnya yang menjadi pertimbangan dalam perubahan Badan Pengelola Air Bersih (BPAB) menjadi Bumdesa yaitu Peraturan Daerah Kabupaten Buleleng Nomor 10 Tahun 2015 Tentang Badan Usaha Milik Desa. Berdasarkan peraturan ini perubahan yang dilakukan memiliki tujuan dalam rangka meningkatkan skala ekonomi pendapatan masyarakat dan desa, maka dari itu pemerintah desa dapat mendirikan Bumdesa sesuai dengan kebutuhan dan potensi dari desanya. Bumdesa ini mengusung konsep Desa Membangun berdasarkan peraturan dari pemerintah.

Tentu dalam pelaksanaannya Bumdesa Bhuana Utama Desa Panji ini memiliki program-program berkelanjutan yang dijalankan agar sesuai dengan tujuan awal dibentuknya Bumdesa ini. Salah satu program yang dirancang dalam Bumdesa ini adalah pelayanan air bersih dengan sistem pembayaran air secara online yang dapat dilakukan oleh masyarakat yang ada di Desa Panji. Pembayaran air secara online ini dapat mengoptimalkan hasil yang didapat oleh desa agar tercapainya kesejahteraan masyarakat (Anugrah et al., 2019). Bumdesa Bhuana Utama mampu memanfaatkan teknologi yang berkembang dan menjadikannya suatu peluang bisnis yang dapat memudahkan pekerjaan manusia, yaitu dengan melakukan pembayaran air secara online. Keuntungan yang didapatkan oleh Bumdesa dari unit usaha pelayanan air minum per tahun 2020 juga dapat dikatakan sangat besar yaitu mencapai ratusan juta rupiah.

Bumdesa Bhuana Utama Desa Panji juga memiliki unit usaha lainnya seperti Simpan Pinjam dan juga pertokoan yang menjual bahan-bahan material bangunan maupun kebutuhan dasar bagi masyarakat. Unit pertokoan pada Bumdesa ini juga turut membantu para pelaku UKM agar dapat memasarkan produknya di Bumdesa ini. Seperti kelompok pembuatan sari jahe merah yang dipasarkan melalui unit pertokoan ini. Pada sistem kredit Bumdesa ini terdapat beberapa pilihan untuk masyarakat, di antaranya kredit musiman dan kredit harian. Kredit yang ditawarkan dalam unit usaha pada Bumdesa ini berguna untuk meningkatkan daya guna dari uang itu sendiri. Kredit juga dapat berperan sebagai stabilitas ekonomi dan juga meningkatkan keinginan masyarakat dalam melakukan kegiatan usahanya sendiri. Kredit ini juga turut berperan besar untuk perkembangan Bumdesa apabila banyak masyarakat yang melakukan pinjaman kepada Bumdesa, karena profit yang didapatkan dari bunga kredit ini cukup besar. 
Terdapat hubungan yang cukup erat di antara ketiga unit bisnis yang dilakukan pada Bumdesa ini. Pada unit pelayanan air bersih dengan sistem pembayaran secara online, maka masyarakat harus mengisi saldo untuk dapat melakukan pembayaran tersebut pada unit tabungan atau simpan pinjam sehingga apabila dilakukan pembayaran air secara online, otomatis saldo pada tabungan akan berkurang. Apabila terdapat kerusakan seperti kebocoran pipa atau masalah lainnya pada pelayanan air bersih ini, maka unit pertokoan memiliki peran dalam meminimalisir permasalahan tersebut. Hal ini dilakukan dengan cara unit pelayanan air bersih akan menggunakan pipa atau bahan material lainnya yang terdapat pada unit pertokoan untuk menghadapi kendala kebocoran pipa atau permasalahan lainnya.

Bumdesa Bhuana Utama tidak hanya berorientasi pada profit, hal ini terbukti dari adanya kegiatan sosial yang dilakukan oleh Bumdesa ini. Adapun kegiatan sosial yang dilakukan oleh Bumdesa ini berupa CSR (Corporate Social Responsibility) untuk memberikan kontribusi terhadap pembangunan berkelanjutan dan mampu memberikan manfaat ekonomi terhadap pihak yang memiliki kepentingan. Kegiatan sosial lainnya yaitu pembagian sembako kepada warga Desa Panji ketika terdapat suatu perayaan seperti perayaan ulang tahun Bumdesa dan ketika Hari Raya Nyepi. Pembagian sembako ini sangat bermanfaat bagi masyarakat terutama masyarakat kurang mampu yang ada di Desa Panji. Manajemen pada Bumdesa khususnya dalam hal ini bagian keuangan harus cermat dalam mengelola keuangan yang terdapat dalam Bumdesa agar seluruh kegiatan operasional yang dilakukan dapat berjalan dengan lancar.

Pembayaran air secara online tentu saja sudah tidak asing lagi didengar pada era teknologi seperti saat ini terutama pada platform besar media digital pada umumnya. Hal berbeda dilakukan oleh Bumdesa Bhuana Utama di Desa Panji, dimana sistem pembayaran air secara online dilakukan hanya untuk masyarakat yang ada di Desa Panji itu sendiri. Berdasarkan penelitian yang dilakukan oleh Anugrah et al., (2019), pengelolaan dana yang masuk ke Bumdesa Bhuana Utama di Desa Panji akan diolah kembali ke desa untuk kemudian digunakan oleh desa adat dan masing-masing banjar sehingga tujuan untuk mensejahterakan masyarakat di Desa Panji menjadi lebih optimal. Hal ini dibuktikan dengan pemberian 30\% laba yang didapatkan oleh Bumdesa diberikan untuk Pendapatan Asli Desa (PAD) di Panji.

Menurut Gede Ganesha selaku masyarakat Desa Panji, ia mengatakan bahwa terdapat manfaat yang dirasakan selaku masyarakat dari penggunaan sistem pembayaran air secara online ini. Hal ini dikarenakan kesibukan dari masing-masing warga Desa yang berbeda-beda sehingga terkadang lupa untuk membayar air yang menyebabkan dikenakannya denda yang sangat tinggi. Dengan adanya sistem pembayaran air secara online, maka warga Desa bisa melakukan pembayaran secara online dengan terlebih dahulu menabung pada Bumdesa sehingga saldo tabungan tersebut bisa digunakan untuk membayar air dimanapun dan kapanpun.

Bumdesa ini juga menyediakan layanan dimana masyarakat bisa membayar air kepada para agen yang tersebar di Desa Panji untuk lebih memudahkan mobilitas apabila terdapat masyarakat yang mengalami kesulitan dalam menggunakan teknologi. Strategi lainnya yang digunakan oleh Bumdesa dalam kegiatan operasional yang dilakukan untuk meningkatkan profit adalah dengan memasang tarif sebesar Rp. 500,- pada setiap transaksi yang dilakukan oleh masyarakat melalui pembayaran air secara online. Walaupun jumlah tarif yang ditetapkan kecil, namun apabila masyarakat yang melakukan transaksi ada banyak maka kalkulasi yang dilakukan akan mendapatkan hasil yang cukup besar. Tarif tersebut juga ditetapkan berdasarkan kemampuan dari masyarakat Desa Panji itu sendiri.

Berdasarkan sistem ini, data yang didapat melalui website lokadata desa, Prasetya (2020) menjelaskan bahwa Bumdesa Bhuana Utama dapat masuk ke dalam daftar tiga terbaik Bumdesa di Kabupaten Buleleng dengan awalnya hanya mengandalkan usaha pengelolaan air 
bersih kemudian dilanjutkan dengan unit simpan pinjam dan unit pertokoan. Menurut data dari Dinas Pemberdayaan Masyarakat dan Desa (PMD) Buleleng yang didapatkan pada website lokadata desa pada tahun 2019, Narayana (2020) menjelaskan bahwa Bumdesa Bhuana Utama telah mampu mendapatkan omzet sebanyak Rp. 1,69 miliar dengan keuntungan senilai Rp. 421,68 juta. Bumdesa ini juga telah mampu memberikan Pendapatan Asli Desa sebesar Rp. 107 juta. Bumdesa juga memberikan bantuan sosial untuk Desa Adat Panji dan Subak Tiing Tali masing-masing sebesar Rp. 17 juta.

Pencapaian ini bisa didapatkan oleh Bumdesa Bhuana Utama berkat pengelolaan manajemen yang baik dilakukan oleh Ketua Bumdesa ini sendiri. Pada saat belum terbentuknya Bumdesa Bhuana Utama dengan kata lain masih di bawah pengelolaan Badan Pengelola Air Bersih (BPAB), banyak masyarakat yang melakukan tunggakan terhadap pembayaran air. Edy selaku Ketua Bumdesa mengatakan bahwa terdapat 3.200 pelanggan air, namun 2.800 di antaranya menunggak dalam pembayaran air karena denda yang diterapkan pada masa itu hanya Rp. 2.000 per bulan. Setelah resmi di bawah pengelolaan Bumdesa dengan Edy selaku Ketua, maka ia melakukan perombakan dengan mengeluarkan sistem pembayaran denda sebanyak Rp. 20.000 per bulan. Warga yang tidak membayar air selama tiga bulan berturut-turut akan dikenakan sanksi berupa pemutusan sambungan.

Berdasarkan pengamatan yang dilakukan oleh Edy yang saat ini berperan sebagai Ketua Bumdesa di Panji, ia mengatakan bahwa manajemen strategi yang dirancang dilakukan sesuai dengan kebiasaan masyarakat di Desa Panji dan selaku Ketua Bumdesa tidak segansegan untuk bersikap tegas apabila ada masyarakat yang melanggar aturan yang telah dibuat oleh Bumdesa itu sendiri. Pengamatan yang dilakukan juga didasarkan bahwa untuk dapat membuat Bumdesa Bhuana Utama menjadi Bumdesa dengan laba ratusan juta bahkan menjadi Bumdesa dengan kategori tiga terbaik di Kabupaten Buleleng menurut data PMD, maka Ketua Bumdesa melakukan analisis terhadap laporan keuangan sebelum Bumdesa Bhuana Utama ini terbentuk, dengan kata lain saat Bumdesa ini masih dikelola oleh Badan Pengelola Air Bersih (BPAB).

Dalam melaksanakan pelayanan terhadap masyarakat, maka dibutuhkan tenaga kerja yang handal dan cepat tanggap dalam membantu masyarakat menangani kebutuhan masyarakat terhadap Bumdesa tersebut. Menurut Haeruddin (2017), motivasi yang tinggi dari para karyawan dapat membuat kelangsungan hidup perusahaan terjamin. Karyawan harus memiliki motivasi kerja yang tinggi melalui usaha dan kerja keras yang dilakukan pada perusahaan. Perusahaan juga harus melakukan suatu dorongan bagi sumber daya manusianya baik dari dalam diri karyawan maupun dari luar. Hal yang dapat dilakukan dengan menumbuhkan motivasi kerja yang tinggi bagi karyawan dapat dilakukan melalui gaji yang diberikan.

Berdasarkan penelitian yang dilakukan tersebut, gaji mempunyai pengaruh yang signifikan terhadap kinerja karyawan. Sejalan dengan hal tersebut, maka Ketua Bumdesa memberikan gaji yang wajar dengan nominal yang seharusnya diterima oleh pegawai di Bumdesa sehingga para pegawai akan merasa dihargai hasil kerjanya dan diharapkan akan meningkatkan kinerja yang diberikan kepada Bumdesa dalam melakukan pelayanan terhadap masyarakat.

Tabel 1. Laba Bersih Sebelum Pajak

\begin{tabular}{cccc}
\hline Tahun 2017 & Tahun 2018 & Tahun 2019 & Tahun 2020 \\
\hline Rp. 234.947.706 & Rp. 409.755.052 & Rp. 421.688.120 & Rp. 536.317.451 \\
\hline
\end{tabular}

Berdasarkan tabel tersebut dapat dilihat bahwa terdapat peningkatan laba bersih sebelum pajak pada Bumdesa Bhuana Utama di Desa Panji. Hal ini sesuai dengan penjelasan 
yang dipaparkan oleh Ketua Bumdesa bahwa terjadinya peningkatan terhadap laba terjadi karena manajemen strategi yang diterapkan berdasarkan informasi yang diperoleh melalui proses akuntansi yang dibuat. Bahkan saat terjadinya pandemi pada tahun 2020 Bumdesa Bhuana Utama ini mampu meningkatkan laba dari tahun sebelumnya, ini membuktikan bahwa akuntansi manajemen strategik sangat dipertimbangkan untuk digunakan oleh manajemen pada Bumdesa.

Peningkatan yang terjadi setiap tahun pada Bumdesa ini juga terjadi akibat penggunaan biaya-biaya yang tepat digunakan oleh pihak Bumdesa. Pada tahun 2020 terjadi peningkatan laba yang cukup tinggi. Hal ini dikarenakan manajemen pada Bumdesa telah membaca situasi yang terjadi sehingga dibuat suatu strategi untuk dapat meningkatkan laba pada Bumdesa. Manajemen Bumdesa mengeluarkan biaya untuk pembuatan aplikasi yang digunakan untuk pembayaran air secara online di Desa Panji. Agar aplikasi ini dapat diketahui oleh seluruh masyarakat di Desa Panji maka manajemen Bumdesa mengeluarkan biaya promosi untuk menyebarluaskan informasi mengenai penggunaan aplikasi pembayaran air secara online ini. Informasi strategik yang digunakan pada laporan laba rugi sebelumnya berfungsi untuk dapat digunakan dalam membuat keputusan-keputusan strategis pada tahuntahun berikutnya.

Berdasarkan penelitian terdahulu yang dilakukan oleh Reswita, (2012) bahwa yang meneliti mengenai hubungan akuntansi manajemen strategik dengan kinerja perusahaan bahwa terdapat hubungan yang kuat antara akuntansi manajemen strategik dengan kinerja perusahaan. Ketua Bumdesa Bhuana Utama juga turut menerapkan akuntansi manajemen strategik untuk menentukan strategi-strategi yang harus dilakukan oleh Bumdesa agar memiliki kinerja perusahaan yang baik, dimana dalam hal ini dapat dilihat melalui kinerja keuangannya dengan salah satu komponennya yaitu laporan laba rugi agar memiliki laba yang tinggi. Akuntansi manajemen strategik ini digunakan untuk membuat keputusan strategi oleh manajemen di Bumdesa berdasarkan hasil laporan keuangan yang telah didapatkan pada periode sebelumnya. Oleh karena itu kinerja keuangan yang dimiliki oleh Bumdesa harus memuaskan dan juga dapat dimengerti oleh pihak yang merancang strategi demi kepentingan Bumdesa. Dalam hal ini manajemen Bumdesa menggunakan laporan laba rugi sebagai acuan dalam menentukan strategi terhadap pihak internal maupun eksternal Bumdesa.

Penelitian terdahulu lainnya yang dilakukan oleh Hertati et al., (2020) mengenai peran manajemen perubahan pada akuntansi manajemen strategis akibat Virus Corona mendapatkan hasil bahwa akuntansi manajemen strategis harus mampu menghadapi suatu ketidakpastian yang dihadapi dengan menggunakan desain tragedi untuk dapat merancang situasi dan kondisi secara cepat dan tepat guna agar dapat beradaptasi untuk menghadapi situasi dan kondisi yang terjadi secara mendadak. Hal ini diterapkan oleh manajemen yang ada di Bumdesa Bhuana Utama bahwa adanya wabah Virus Corona yang menyerang dunia tidak membuat laba yang dihasilkan oleh Bumdesa menjadi turun akibat dari perencanaan manajemen strategi yang dilakukan dapat diprediksi dan tepat guna.

Penelitian terdahulu yang dilakukan oleh Setiawan (2017) mengenai hubungan rating bintang terhadap peran akuntansi manajemen strategis yang dilakukan pada perusahaan hotel di Sumatera Selatan mendapatkan hasil bahwa akuntansi manajemen strategik memiliki peran dalam meningkatkan rating bintang pada perusahaan hotel tersebut dimana akuntansi manajemen strategik digunakan untuk menghasilkan informasi strategis bagi manajemen dengan didukung oleh fungsional akuntansi yang handal untuk menyediakan informasiinformasi strategis bagi manajemen untuk kemudian menentukan kebijakan dan keputusan strategis bagi perusahaan.

Teori yang digunakan pada penelitian ini adalah teori yang berkaitan dengan akuntansi manajemen strategik. Menurut Reswita (2012), akuntansi manajemen strategik harus dapat digunakan untuk menganalisis dan meninjau ke dalam maupun ke luar organisasi 
sehingga sistem akuntansi manajemen strategik ini menjadi tepat guna dan menguntungkan bagi pihak intern maupun ekstern organisasi. Akuntansi manajemen strategik ini dapat digunakan untuk mengambil keputusan yang memiliki kaitan dengan operasi bisnis dan menganalisa isu-isu strategis berdasarkan administrasi keuangan pada suatu organisasi.

Teori lainnya yang berkaitan adalah manajemen strategik. Menurut Prasetyo (2018), manajemen strategik diartikan sebagai proses atau suatu rangkaian kegiatan dalam pengambilan keputusan yang bersifat mendasar dan menyeluruh dengan disertai penetapan cara melaksanakannya. Manajemen strategik ini dibuat oleh manajemen puncak untuk dapat diimplementasikan kepada seluruh jajaran di dalam suatu organisasi agar dapat mencapai tujuan organisasi. Manajemen strategik juga digunakan untuk mampu menumbuhkembangkan kekuatan organisasi guna mengeksploitasi peluang yang muncul untuk mencapai tujuan yang telah ditetapkan sesuai misi yang telah ditentukan.

Teori yang berkaitan dengan kinerja keuangan juga menunjang penelitian ini. Makatita (2016) menyatakan bahwa kualitas kinerja keuangan yang baik merupakan dapat menjadi hal penting bagi perkembangan operasional perusahaan. Untuk dapat memutuskan suatu perusahaan memiliki kualitas kinerja yang baik dapat dilakukan melalui penilaian berdasarkan kinerja keuangan dengan melihat pada laporan keuangan yang dimiliki oleh suatu perusahaan. Informasi pada kinerja keuangan tersebut dapat dilihat dan diperoleh pada neraca, laporan laba rugi, dan laporan arus kas, serta hal lainnya yang mendukung penguatan terhadap penilaian kinerja keuangan. Para manajer dalam suatu perusahaan juga diharapkan untuk memiliki pengetahuan yang baik mengenai teknik analisis kinerja keuangan sehingga dapat mendukung dalam pengambilan keputusan baik investasi, pendanaan, maupun likuiditas dengan tujuan untuk membuat perusahaan memiliki tingkat kesejahteraan yang tinggi.

Berdasarkan pemaparan di atas maka tujuan dari penelitian ini adalah untuk mengungkap praktek akuntansi manajemen strategik terhadap kinerja keuangan pada Badan Usaha Milik Desa (Bumdesa) Bhuana Utama Desa Panji.

\section{Metode}

Metode yang digunakan pada penelitian ini adalah metode deskriptif kualitatif yang dimulai dari ditemukannya suatu keunikan dari sebuah badan usaha di salah satu Desa di Buleleng yaitu dalam waktu kurang dari lima tahun, Bumdesa ini telah mampu menjadi Bumdesa ke-tiga terbaik di Kabupaten Buleleng dengan laba mencapai ratusan juta rupiah. Bahkan pada masa pandemi yang terjadi pada tahun 2020, Bumdesa Panji masih mampu untuk meningkatkan labanya. Peneliti tertarik untuk mengetahui praktik akuntansi manajemen strategik yang dilakukan oleh pihak Bumdesa kepada masyarakat Desa Panji dan stakeholder lainnya dengan melihat laporan laba rugi pada Bumdesa ini. Peneliti kemudian melakukan pendalaman terhadap keunikan ini dengan melakukan observasi awal guna mengumpulkan data dan informasi yang berkaitan dengan praktik akuntansi manajemen strategik sehingga mendapatkan laba yang tinggi pada Bumdesa Bhuana Utama Desa Panji. Selanjutnya peneliti juga melihat bagaimana subjek atau informan memaknai kejadian yang terjadi seperti bagaimana laporan laba rugi digunakan untuk perencanaan strategi dengan melakukan wawancara yang mendalam kepada informan.

Subjek penelitian atau informan yang akan menjadi narasumber dalam penelitian ini adalah Ketua, Sekretaris, Bendahara Bumdesa, Kepala Desa atau perangkat pemerintah Desa, Badan Pengawas Bumdesa, serta masyarakat yang turut merasakan manfaat dari adanya Bumdesa Bhuana Utama Desa Panji. Adapun variabel dalam penelitian ini adalah akuntansi manajemen strategik yaitu suatu proses yang dilakukan dengan menyusun manajemen strategi yang digunakan untuk meningkatkan kinerja perusahaan berdasarkan laporan 
keuangan yang telah dibuat. Teknik pengumpulan data yang digunakan dalam penelitian ini yaitu melalui triangulasi data yaitu wawancara, observasi, dan analisis dokumen.

Metode wawancara yang digunakan dalam penelitian ini adalah wawancara terstruktur, dimana peneliti telah menyiapkan daftar pertanyaan secara terstruktur dan menggunakan alat bantu seperti catatan dan alat perekam. Observasi pada penelitian ini dilakukan melalui pengamatan langsung terhadap praktik akuntansi manajemen strategik yang dilakukan oleh manajemen Bumdesa di Desa Panji. Dalam penelitian ini juga dilakukan analisis terhadap dokumen-dokumen seperti salah satu komponen laporan keuangan Bumdesa Bhuana Utama Desa Panji yaitu laporan laba rugi tahun 2017-2020. Dokumen lainnya pada Bumdesa yang digunakan untuk mendukung penelitian ini adalah Standar Operasional Prosedur (SOP) Bumdesa Bhuana Utama Desa Panji dan Profil Bumdesa Panji.

\section{Hasil dan Pembahasan}

\section{Gambaran Umum Desa Panji}

Desa Panji adalah sebuah desa yang terletak di Kecamatan Sukasada, Kabupaten Buleleng, Bali. Desa ini terletak pada ketinggian 315 meter dari permukaan laut dengan luas wilayah 1061 ha. Desa Panji ini memiliki beberapa potensi dari berbagai sektor untuk dapat meningkatkan perekonomian masyarakatnya. Adapun sektor-sektor yang menjadi potensi desa tersebut yaitu terhadap sektor pertanian, sektor perkebunan, sektor pertenakan, sektor kerajinan, dan sektor pariwisata.

\section{Gambaran Umum Badan Usaha Milik Desa Bhuana Utama Desa Panji}

Badan Usaha Milik Desa (Bumdesa) Bhuana Utama Desa Panji ini terletak di Jalan Kibarak Panji Sakti No. 88, Desa Panji, Kecamatan Sukasada, Kabupaten Buleleng, Bali. Bumdesa ini berdiri pada tanggal 16 Desember 2016 dan mulai beroperasi pada tanggal 26 Juli 2017. Pada awal berdirinya Bumdesa terdapat penyertaan Dana Desa dengan jumlah Rp. 50.000.000, Bantuan Kemendes sebesar Rp. 50.000.000, dan hibah dari pemerintah desa yang awalnya dikelola oleh Badan Pengelola Air Bersih (BPAB) yang berupa asset dank as sebesar Rp. 360.000.000.

Badan Usaha Milik Desa ini merupakan suatu instrumen organisasi yang digunakan dalam pendayagunaan ekonomi lokal yang memiliki berbagai jenis potensi. Pendayagunaan potensi yang dilakukan ini memiliki tujuan untuk peningkatan kesejahteraan ekonomi warga desa di Panji. Keorganisasian Badan Usaha Milik Desa Bhuana Utama Desa Panji ini terdiri dari Penasehat, Pengawas, Pelaksana Operasional, dan juga beberapa staff.

Berdasarkan data yang didapatkan oleh peneliti setelah melakukan observasi awal, maka diketahui bahwa Bumdesa Panji ini memiliki 3 unit usaha dalam rangka untuk meningkatkan kesejahteraan rakyatnya. Unit yang pertama kali ada pada Bumdesa yaitu unit pelayanan air bersih, kemudian dikembangkan unit simpan pinjam, lalu menyusul unit toserba. Unit-unit ini dikembangkan berdasarkan perencanaan strategi yang telah dibuat sebelumnya.

\section{Kinerja Keuangan Badan Usaha Milik Desa Bhuana Utama Desa Panji}

Dalam meningkatkan kinerja keuangan Bumdesa Panji maka manajemen melakukan perencanaan terkait dengan kegiatan-kegiatan yang akan dilakukan di masa mendatang. Perencanaan ini dapat berupa strategi-strategi yang akan dijalankan oleh Bumdesa terkait dengan kegiatan operasional yang dilakukan. Perencanaan dalam strategi yang dilakukan untuk meningkatkan kualitas Bumdesa ini didasarkan pada laporan keuangan yang telah dibuat.

Laporan laba rugi yang dibuat oleh Bumdesa ini juga dapat berfungsi sebagai tolak ukur untuk mengetahui apakah strategi yang direncanakan oleh Bumdesa sudah tepat atau 
belum. Apabila Bumdesa mendapatkan laba bersih yang maksimal dan sesuai dengan target Bumdesa maka strategi yang diterapkan sudah tepat, namun apabila Bumdesa mengalami hal yang sebaliknya yaitu laba bersih tidak sesuai dengan target maka diperlukan suatu evaluasi untuk menilai ketidaktepatan strategi yang diterapkan oleh Bumdesa sehingga tidak mencapai target.

Berdasarkan analisis dokumen yang dilakukan oleh peneliti, terdapat biaya yang tidak dikeluarkan oleh Bumdesa pada tahun sebelumnya yaitu biaya konsumsi dan biaya rapat. Peneliti menganalisis bahwa tidak dikeluarkannya biaya ini dikarenakan adanya pandemi Covid yang terjadi pada tahun 2020 yang menyebabkan semua kegiatan diharuskan untuk dilakukan dari rumah dan menggunakan media virtual saat mengadakan pertemuan. Sehingga biaya konsumsi dan biaya rapat dapat ditekan oleh Bumdesa. Namun untuk tetap memaksimalkan layanan yang ada, Bumdesa membayar biaya aplikasi dan biaya promosi untuk kelancaran usaha dan kepuasan pelanggan.

Laporan laba rugi yang dibuat oleh Bumdesa ini juga dapat berfungsi sebagai tolak ukur untuk mengetahui apakah strategi yang direncanakan oleh Bumdesa sudah tepat atau belum. Apabila Bumdesa mendapatkan laba bersih yang maksimal dan sesuai dengan target Bumdesa maka strategi yang diterapkan sudah tepat, namun apabila Bumdesa mengalami hal yang sebaliknya yaitu laba bersih tidak sesuai dengan target maka diperlukan suatu evaluasi untuk menilai ketidaktepatan strategi yang diterapkan oleh Bumdesa sehingga tidak mencapai target.

Perencanaan strategi yang dilakukan oleh manajemen Bumdesa ini bisa dilakukan karena terdapat laporan keuangan yang baik dibuat oleh Bendahara pada Bumdesa yang menyebabkan kinerja keuangan menjadi baik. Kinerja keuangan pada Bumdesa dapat dikatakan baik karena laba yang didapatkan setiap tahunnya dapat meningkat di bawah pengelolaan manajemen Bumdesa. Dibandingkan jika masih di bawah pengelolaan Badan Pengelola Air Bersih (BPAB) dimana laporan keuangan yang dibuat tidak teratur sehingga tidak bisa dijadikan acuan dalam pengambilan keputusan selanjutnya yang dilakukan oleh manajemen dalam memajukan organisasinya. Laba yang didapatkan pada Bumdesa dapat meningkat karena pendapatan yang didapatkan ketika pengelolaan Bumdesa ini mengalami kenaikan. Hal ini dikarenakan adanya peningkatan pelanggan yang menggunakan layanan pada Bumdesa dibanding BPAB sebelumnya.

\section{Akuntansi Manajemen Strategik pada Badan Usaha Milik Desa Bhuana Utama Desa Panji}

Badan Usaha Milik Desa (Bumdesa) Bhuana Utama Desa Panji dalam menjalankan kegiatan operasionalnya selalu melakukan analisis terlebih dahulu terhadap kegiatan-kegiatan yang akan dilakukan ke depannya. Hal ini dilakukan agar program yang dijalankan tepat sasaran dan sesuai dengan target yang diinginkan oleh manajemen pada Bumdesa. Berbagai cara dilakukan oleh Bumdesa untuk dapat menarik pelanggan yang menggunakan layanan yang terdapat pada Bumdesa.

Terdapat suatu sistem yang berbeda dilakukan oleh manajemen Bumdesa saat pembayaran air oleh pelanggan. Sistem yang digunakan adalah pembayaran air secara online. Sistem pembayaran air secara online ini dirancang melalui perencanaan strategis untuk memudahkan pelanggan dalam melakukan pembayaran. Dengan adanya fitur pembayaran berbasis Android ini makan pelanggan dapat dengan sangat mudah untuk mengecek jumlah tagihan air dan juga memantau mengenai informasi air bersih setiap saat. Selain adanya kemudahan yang diberikan untuk pelanggan, sistem yang digunakan juga memudahkan bagi karyawan lapangan Bumdesa karena dapat melakukan pengecekan debit kilometer pelanggan air hanya menggunakan handphone, dibanding dulu yang menggunakan buku besar. 
Sistem informasi yang diterapkan ini menjadi lebih transparan karena bisa diakses oleh dua pihak, baik pelanggan maupun karyawan. Fitur ini dapat diakses melalui website https://pam.bumdesaku.id dan terlebih dahulu menabung pada unit simpan pinjam di Bumdesa untuk mengisi saldo yang kemudian digunakan untuk melakukan pembayaran air. Pelanggan juga dapat berinteraksi pada sistem ini dengan memberikan laporan, keluhan, maupun masukan terhadap kinerja Bumdesa selaku pengelola air bersih. Apabila terdapat pelanggan yang memiliki keluhan terhadap kebocoran pipa ataupun masalah teknis lainnya, maka teknis dari Bumdesa akan segera melakukan perbaikan. Perbaikan yang dilakukan mengenai kebocoran pipa ini akan bekerjasama dengan unit toserba, dimana teknisi akan menukar nota pada unit toserba untuk mendapatkan bahan-bahan maupun perlengkapan yang digunakan untuk memperbaiki kerusakan pada pelanggan tersebut.

Dengan membuka tabungan pada unit simpan pinjam, maka pelanggan juga mendapat kemudahan apabila melakukan transaksi pada unit toserba karena unit ini mendukung penggunaan transaksi dengan sistem pembayaran pada produk di Bumdesa yang dilakukan melalui transfer tunai atau melalui kode QR sehingga akan mengurangi saldo yang sudah dibayarkan melalui unit simpan pinjam.

Bumdesa Panji juga memperhatikan aspek sosial dalam menjalankan kegiatan Bumdesa melalui adanya Corporate Social Responsibility (CSR) yang digunakan oleh masyarakat yang ingin meminta bantuan dana kepada Bumdesa. CSR ini dilakukan untuk membantu para muda-mudi dalam melakukan kegiatan serta ketika Bumdesa merayakan HUT Bumdesa maka dilaksanakan pembagian sembako untuk para lansia.

Untuk dapat mewujudkan kesejahteraan masyarakat ini maka diperlukan suatu strategi dengan perencanaan matang yang dibuat oleh manajemen pada Bumdesa dengan berbagai pertimbangan yang diberikan oleh penasehat. Manajemen strategi yang dibuat ini tentu didasarkan pada sebuah acuan yang dapat digunakan untuk mengambil suatu keputusan ke depannya. Salah satu acuan yang digunakan oleh Bumdesa Panji ini dalam merancang strategi adalah laporan laba rugi per tahunnya.

Penting bagi manajemen Bumdesa untuk merancang juga strategi yang akan digunakan untuk mempertahankan kelangsungan usaha Bumdesa itu sendiri. Hal ini dilakukan untuk berjaga-jaga terhadap situasi yang akan terjadi ke depannya. Contohnya seperti pandemi Covid yang sedang terjadi, maka manajemen dituntut untuk mampu minimal mempertahankan laba yang didapatkan oleh Bumdesa. Segala macam tindakan yang dilakukan oleh manajemen pada Bumdesa ini dilakukan berdasarkan analisis mendalam yang dilakukan di lapangan agar strategi yang dibentuk dapat tepat sasaran. Seperti penentuan pada perhitungan tarif dalam pembayaran air pelanggan. Dalam pembayaran air, pembayaran yang dilakukan dibedakan berdasarkan kapasitasnya.

Berdasarkan standar operasional prosedur Bumdesa Bhuana Utama Desa Panji, para pelanggan yang membayar tarif air dilakukan mulai tanggal 5 hingga tanggal 25 setiap bulannya. Apabila terdapat pelanggan yang terlambat dalam melakukan pembayaran, maka manajemen mengeluarkan kebijakan yang mengharuskan para pelanggan untuk membayar denda sebesar Rp. 20.000. Jika dilihat dari nominal tarif pembayaran air per $\mathrm{m}^{3}$ yang harus dibayarkan pada masing-masing kategori tersebut dan dibandingkan dengan denda yang harus dibayarkan maka dapat dianalisis bahwa pelanggan kemungkinan akan membayar denda lebih mahal dibandingkan pembayaran air semestinya yang harus dibayarkan. Hal ini dilakukan berdasarkan pertimbangan para manajemen Bumdesa untuk menekan adanya tunggakan dalam pembayaran air. Terbukti atas adanya kebijakan ini maka Bumdesa dapat mengurangi jumlah pelanggan yang melakukan tunggakan terhadap pembayaran air.

Berdasarkan strategi yang telah direncanakan oleh Bumdesa, masih terdapat beberapa kendala yang dialami, dari segi pembuatan laporan keuangan Bendahara Bumdesa mengalami kendala karena Bumdesa saat ini masih membuat laporan keuangan secara 
manual yang disebabkan karena Bumdesa masih mempersiapkan program accounting untuk mempermudah pekerjaan Bendahara, selain itu juga pemahaman mengenai perpajakan masih menjadi kendala dalam melakukan pelaporan pajak. Masyarakat sendiri mengalami kendala saat melakukan transaksi pada toserba Bumdesa karena tempatnya yang cukup kecil.

Strategi yang direncanakan oleh manajemen Bumdesa untuk ke depannya agar bisa meningkatkan laba dengan tidak mengesampingkan tujuan utama dari Bumdesa yaitu untuk meningkatkan kesejahteraan ekonomi masyarakat di Panji yaitu dengan berupaya melakukan kolaborasi bersama PKK dan KWT untuk memasarkan hasil dari produk-produk yang telah dibuat dan nantinya bisa ditambahkan di toserba Bumdesa. Selain membantu KWT untuk memasarkan produknya, Bumdesa juga mendapatkan keuntungan dari produk yang dijual karena perbedaan harga yang diberikan oleh KWT kepada Bumdesa karena menjadi reseller dalam pemasaran produk KWT oleh Bumdesa.

Dalam bidang pariwisata, Bumdesa sedang melakukan upaya untuk mengembangkan destinasi-destinasi wisata baru yang nantinya akan dikelola oleh Pokdarwis yang bekerjasama dengan Bumdesa. Peran Bumdesa sendiri adalah dengan memberikan support dan memberikan fasilitas berupa ticketing dan sistem pembayaran yang nantinya akan memberikan masukan pendapatan juga untuk Bumdesa.

Bumdesa Panji juga sedang berusaha untuk menyusun Peraturan Desa yang mengatur mengenai kenaikan harga air yang berhubungan dengan retribusi air. Hal ini dikarenakan harga air di Panji terlampau sangat murah jika dibandingkan dengan PDAM, jika dilakukan peningkatan tarif air namun tetap di bawah tarif PDAM maka tidak akan merugikan masyarakat. Perencanaan ini ditargetkan akan bisa dilakukan pada tahun mendatang sehingga hal ini dapat meningkatkan pendapatan dari Bumdesa ini.

Target dari Bumdesa ke depannya juga adalah dengan menjadikan Lembaga Pengelola Hutan Desa (LPHD) sebagai salah satu unit dari Bumdesa untuk bagian pengelola hutan. Pengelolaan hutan ini harus dilakukan dengan baik dan membutuhkan bantuan dari Bumdesa dengan cara memberikan modal awal untuk melakukan investasi dalam pengelolaan. Hal ini dikarenakan Bumdesa juga berkepentingan mengenai hutan desa ini karena Bumdesa berperan dalam pengelolaan airnya. Dalam hal ini Bumdesa dapat melakukan pengadaan penghijauan untuk menjaga mata air agar tetap bersih dan tidak surut.

Badan Usaha Milik Desa (Bumdesa) Bhuana Utama Desa Panji sudah menjalankan fungsinya sebagai lembaga yang bertujuan untuk meningkatkan skala perekonomian masyarakat di Desa Panji. Hal ini dibuktikan berdasarkan terserapnya jumlah karyawan yang berasal dari Desa Panji itu sendiri sehingga mampu mengurangi pengangguran. Bumdesa Panji juga mampu memberikan kontribusi terhadap Desa dengan memberikan Pendapatan Asli Desa (PAD) terhadap Desa Panji sebanyak 30\% dari jumlah laba yang didapatkan tiap tahunnya. Jumlah laba yang didapatkan oleh Bumdesa Panji mengalami kenaikan sejak mulai dijalankannya Bumdesa ini pada tahun 2017. Ini diakibatkan oleh perencanaan strategis yang baik dilakukan oleh manajemen dengan didasarkan pada situasi mapun kondisi di Desa Panji dan juga laporan keuangan yang dibuat oleh Bumdesa.

Laporan keuangan yang dibuat ini digunakan sebagai acuan untuk menentukan keputusan yang diambil oleh manajemen dalam perencanaan strategi yang akan dijalankan Bumdesa untuk meningkatkan kualitas layanan ke depannya. Bumdesa Bhuana Utama Desa Panji dapat dikatakan berhasil dalam merancang strategi untuk Bumdesa, hal ini dibuktikan dengan semakin meningkatnya laba yang diperoleh oleh Bumdesa dari tahun ke tahun. Manajemen strategi yang dibuat ini sebelum dijalankan tentu mendapat masukan dan pengarahan dari penasehat Bumdesa yang juga menjabat sebagai Kepala Desa Panji.

Ketiga unit bisnis yang terdapat pada Bumdesa seperti unit pelayanan air bersih, unit simpan pinjam, dan unit toserba dijalankan dengan optimal agar mendapatkan hasil sesuai 
dengan target yang ditetapkan Bumdesa. Adapun beberapa strategi yang dirancang oleh Bumdesa ini berupa peningkatan denda, peningkatan kualitas, maupun pemberian gaji yang layak kepada para karyawan untuk meningkatkan semangat kerja. Setiap kegiatan operasional yang dilakukan oleh Bumdesa ini diawasi oleh Badan Pengawas Bumdesa yang terdiri dari Ketua, Sekretaris, dan Anggota dengan pembagian tugas yang berbeda-beda.

\section{Simpulan dan Saran}

Kesimpulan yang dapat diberikan dalam penelitian ini adalah perencanaan strategi yang dibuat oleh manajemen dilakukan berdasarkan laporan keuangan tahun sebelumnya yang pernah dibuat dan dilaporkan saat diadakannya musyawarah desa yang dihadiri oleh penasehat, dan juga tokoh-tokoh penting yang akan memberikan pertimbangan juga terhadap Bumdesa. Manajemen strategi yang dibuat oleh Bumdesa juga dibuat dengan mempertimbangkan segala aspek yang ada di masyarakat dan melihat potensi yang ada di Desa Panji. Segala perencanaan yang dilakukan oleh Bumdesa ini bertujuan untuk meningkatkan kesejahteraan bagi masyarakat yang ada di Desa Panji.

Saran yang dapat diberikan oleh peneliti yaitu Bumdesa Panji agar lebih menggali potensi di Desa Panji dan membuat perencanaan yang matang sehingga dapat menambah unit baru di Bumdesa. Dengan bertambahnya unit baru maka akan semakin memperluas lapangan pekerjaan di Desa Panji. Luasnya lapangan pekerjaan ini akan membuat kesejahteraan ekonomi bagi masyarakat di Desa Panji. Hal ini juga dapat menguntungkan bagi Bumdesa karena dapat meningkatkan pendapatan setiap tahunnya.

\section{Daftar Pustaka}

Anugrah, G. F. W., Yasa, I. N. P., \& Sujana, E. (2019). Analisis Perbedaan Dasar Perhitungan Tarif Harga Air Bersih dan Pengelolaan Dana Pamdes di Bumdes Bhuana Utama (Studi Pada BUMDes Bhuana Utama Desa Panji, Kecamatan Sukasada, Kabupaten Buleleng, Provinsi Bali). 9(3), 263-272.

Haeruddin, M. I. M. (2017). Pengaruh Gaji dan Insentif terhadap Kinerja Karyawan dan Organisational Citizenship Behaviour ( OCB ) pada Hotel Grand Clarion di Makassar. Aplikasi Manajemen Ekonomi Dan Bisnis, 2(1), 11-21.

Hertati, L., Syafarudin, A., \& Safkaur, O. (2020). Peran Manajemen Perubahan Pada Akuntansi Manajemen Strategis Akibat Virus Corona. I-FINANCE: A Research Journal on Islamic Finance, 06(02), 106-124.

Kurniawan, W. D. W., Wisnawa, I. G. Y., \& Jayantara, I. G. N. Y. (2020). Pengembangan Hutan Wisata Terintegrasi Berbasiskan Prinsip Pembangunan Berkelanjutan Di Desa Panji, Buleleng. 737-742.

Makatita, R. F. (2016). Pentingnya Kinerja Keuangan Dalam Mengatasi Kesulitan Keuangan Perusahaan: Suatu Tinjauan Teoritis Reyner F. Makatita. Journal Of Management (SME's), 2(1), 137-150.

Narayana, K. (2020). Kiat “"putus air"” Bhuana Utama. Lokadata Desa. https://desa.lokadata.id/artikel/kiat-putus-air-bhuana-utama

Prasetya, E. (2020). BUMDes di Buleleng, dari layanan air ke digital. Lokadata Desa. https://desa.lokadata.id/artikel/bumdes-di-buleleng-dari-layanan-air-ke-digital 
Reswita, Y. (2012). Prioritas Strategi, Akuntansi Manajemen Strategik dan Kinerja Perusahaan (Studi: Perusahaan-Perusahaan Elektronik di Kota Batam.

Setiawan, A. S. (2017). Hubungan Rating Bintang Terhadap Peran Akuntansi Manajemen Strategis (Studi Empiris Pada Perusahaan Hotel di Sumatera Selatan). Jurnal Akuntansi, XXI(01), 114-126. 